Author version: Quat. Int., vol.313-314; 2013; 230-239

\title{
The origin of ferro-manganese oxide coated pumice from the Central Indian Ocean Basin
}

J. N. $\operatorname{Pattan}^{1 *}$, N. J. G. Pearce ${ }^{2}$, G. Parthiban ${ }^{1}$, V.C. Smith $^{3}$, Abhay V.Mudholkar, ${ }^{1}$ N.Rajeshwara.Rao ${ }^{4}$

\author{
${ }^{1}$ CSIR-National Institute of Oceanography, Dona Paula, 403 004, Goa, India \\ ${ }^{2}$ Institute of Geography and Earth Sciences, Aberystwyth University, SY23 3DB, Wales, United Kingdom \\ ${ }^{3}$ Research Laboratory for Archaeology and the History of Art, University of Oxford, Dyson Perrins Building, \\ South Parks Rd, Oxford University, OX1 3QY, United Kingdom. \\ ${ }^{4}$ Department of Applied Geology, University of Madras, Maraimalai Campus, Guindy, Chennai-600025.
}

\section{A B S T R A C T}

Pumice clasts, partially and fully coated with ferro-manganese oxide from the Central Indian Ocean Basin (CIOB) were analysed for major, trace and rare earth elements; and glass and mineral grain chemistry to assess their possible source. These pumice clasts have $\sim 95 \%$ glassy matrix with $\sim 5 \%$ of plagioclase, ortho-pyroxene, amphibole and spinel mineral grains. Pumice is rhyolitic, with high content of silica and total alkalis and show strong light rare earth element enrichment, with La $\sim 100$ times enriched compared to chondritic abundance and exhibits a pronounced negative Eu-anomaly. Both the partially and fully coated pumice clasts have a similar composition, but this, and their, glass and mineral (orthopyroxene) chemistry differs from all tuffs known to have erupted from the Toba Caldera Complex. The partial to complete Fe-Mn oxide coating suggests pumice probably predate activity from the Toba caldera. Their general composition is consistent with a volcanic arc origin, and show similarities to rhyolitic eruptives from Sumatra. The distribution of partially and fully coated pumice in the CIOB overlaps with that of uncoated pumice from the voluminous YTT eruption, suggesting that other large rhyolitic calderas active in Sumatra/Indonesia. Similarities in composition to ash layers from the CIOB suggest a possible Late Miocene - Late Pleistocene age for these pumices.

*Corresponding author. Tel,91-832-2450360. Fax, 91-832-2450609.

E-mail,*pattan@nio.org, nick.pearce@aber.ac.uk, parthi@nio.org, victoria.smith@rlaha.ox.ac.uk, abhay@nio.org, raonandamuri@gmail.com 


\section{Introduction}

Pumice, a vesicular volcanic rock with a predominantly glassy matrix, floats on water for many months because of its low bulk density $\left(0.5-0.7 \mathrm{gm} / \mathrm{cm}^{3}\right)$, and thus is transported by the ocean currents over thousands of kilometers. Pumice is reported in all the world's oceans and along many of the beaches and coasts. It can reach the oceans as fallout from Plinian eruption columns, ignimbrites that either flow into the oceans or are deposited in major drainage system or shallow $(<500 \mathrm{~m})$ subaqueous vents (Allen et al., 2010). A large pumice field covering $\sim 600,000 \mathrm{~km}^{2}$ area in the Central Indian Ocean Basin (CIOB) has been reported by Iyer and Sudhakar (1993). Pumice retrieved from the CIOB can be uncoated, to fully coated with Fe-Mn oxides. Many of these pumice fragments have partial Fe-Mn oxide deposition along their rim with spots and patches of oxide surrounding uncoated areas. Accretion of Fe-Mn oxide is very slow, $\sim 1 \mathrm{~mm} / \mathrm{Ma}$ (Banakar, 1990); thus, uncoated pumice is considered to be much younger compared to partially or fully coated grains. The largest pumice clast recovered by dredging from the CIOB is $24 \mathrm{~cm} \mathrm{x} 18 \mathrm{~cm} \mathrm{x} 14 \mathrm{~cm}$ size and is partially coated with Fe-Mn oxide.

Pumice in the oceanic environment provides a means of tracking oceanic circulation (Jokiel and Cox, 2003), and is important for understanding biogeographical and ecological dispersal of terrestrial and marine organisms (de Vantie, 1992). Floating pumice slowly absorbs water into its vesicles depending on the fragment size, initial density, vesicle size, and permeability (Whitham and Sparks, 1986) and eventually sinks to the seafloor. Pumice clasts can act as nuclei for the deposition of ferromanganese nodules (Martin-Barajas and Lallier-Vergès, 1993). In the CIOB, the thickness of Fe-Mn oxide on pumice clasts reaches up to a maximum of $\sim 10 \mathrm{~mm}$, suggesting the accretion could have occurred over $\sim 10$ Ma because $1 \mathrm{~mm}$ of Fe-Mn oxide accretion takes $\sim 1 \mathrm{Ma}$. Several sources for the pumice recovered from the CIOB have been suggested, including in-situ submarine silicic volcanic activity (Hedervari, 1982; Iyer and Sudhakar, 1993); the 1883 - Krakatau eruption (Mudholkar and Fujii, 1995; Pattan et al., 2008); Indonesian Arc Volcanism (Iyer and Karisiddaiah, 1988; MartinBarajas and Lallier-Vergès, 1993) and the Youngest Toba Tuff (YTT) eruption (northern Sumatra) at $\sim 74$ ka (Pattan et al., 2008). Pumice from the 1883- Krakatau eruption drifted to most of the Indian Ocean coasts (Frick and Kent, 1984) while pumice from the YTT is known to have drifted into the CIOB (Pattan et al., 2008). The other possible sources of pumice could be Middle Toba Tuff (MTT) of 0.5 Ma, Oldest Toba Tuff (OTT) of 0.84 Ma and Haranggoal Dacite Tuff (HDT) of 1.2 Ma old. The relatively young pumice fragments should, at present, be free of Fe-Mn oxide coatings, whereas older pumice should become progressively more encrusted, with coating thickness providing some 
constraints on the age of the pumice. This approximate age, when combined with the compositional "fingerprint" of pumice, may allow the identification of a probable source. The present study of partially to fully ferro-manganese oxide coated pumice recovered from the CIOB, attempts to identify their possible source by analysing their bulk sample major and trace element composition, along with glass phase and mineral chemistry.

\section{Material and Methods}

Numerous cruises investigating ferro-manganese nodules in the $\mathrm{CIOB}$ (between $10^{\circ} \mathrm{S}$ to $20^{\circ} \mathrm{S}$ and $72^{\circ} \mathrm{E}$ to $84^{\circ} \mathrm{E}$, Fig.1) collected a large number of pumice clasts, uncoated to fully coated with Fe-Mn oxides, in grabs and dredges. The bottom of the dredge has a synthetic mesh net with 2 × $2 \mathrm{~cm}$ squares, and thus the dredge will only collect large fragments. Surprisingly, during a single dredge haul, pumice clasts were recovered which are uncoated (implying a young age) or partially to fully coated with Fe-Mn oxide up to a few mm thick (older age), suggesting that pumices of different ages are recovered from the sea bed in a single haul, some with long residence times on the sea bed. The dredging operation on the seafloor normally mixes at least the top $50 \mathrm{~cm}$ of the sediment column, which may represent $\sim 200-250 \mathrm{ka}$ (Banakar et al., 1991). In the present study, 20 partially coated pumice clasts with $\sim 1 \mathrm{~mm}$ of Fe-Mn oxide, and five fully coated clasts, with Fe-Mn oxide $\sim 2-4 \mathrm{~mm}$ thick were selected for analysis. Of the partially coated pumice fragments, 6 have long axes between $2-4 \mathrm{~cm}$; 5 each are between $4-6 \mathrm{~cm}$ and $6-8 \mathrm{~cm}$; and four are between $8-10 \mathrm{~cm}$. From the fully coated pumices, two are $4-6 \mathrm{~cm}$ and the remaining two $6-8 \mathrm{~cm}$ along the long axis.

For bulk analysis, the clasts were finely powdered and leached with $6 \mathrm{~N} \mathrm{HCl}$ to remove all Fe-Mn oxide coatings, and subsequently washed and dried. The cleaned pumice residue from the partially and fully coated fragments was analysed by X-ray fluorescence (XRF) for its major element composition at the National Geophysical Research Institute, Hyderabad, and National Institute of Oceanography, Goa, India. Aliquots of these bulk samples were analysed by inductively coupled plasma-mass spectrometer (ICP-MS) at both Aberystwyth University and at the National Institute of Oceanography, Goa, for trace and rare earth elements following methods described by Pearce et al. (2004). Accuracy for major element analysis was checked using the Geological Survey of Japan reference material JR-1, and is well within the acceptable limits (see Table 1). Trace element accuracy was assessed by the analysis of the USGS Certified Reference Material QLO-1 (USGS, 2006). This gave results typically within $\pm 5 \%$ of recommended or certified values, and in all cases determined concentrations were within the quoted uncertainty of accepted values. Trace element analytical precision was determined by analyses of several duplicate samples, and was typically 
better than $\pm 5 \%$. Selected partially and fully Fe-Mn oxide coated pumice samples were analysed by electron probe micro analysis (EPMA) for glass and mineral chemistry. Glass analysis was also performed to investigate whether the leaching with $6 \mathrm{~N} \mathrm{HCl}$ had caused any compositional changes in the glass (to assist in the interpretation of the bulk chemical data). Glass and mineral compositions were determined using Jeol 8600 electron microprobe (EPMA), equipped with 4 spectrometers and SamX software, at the Research Laboratory for Archaeology and the History of Art, University of Oxford. An accelerating voltage of $15 \mathrm{kV}$, a low beam current $(6 \mathrm{nA})$, and a defocused $(10 \mu \mathrm{m})$ beam were used to minimize $\mathrm{Na}$ migration. The instrument was calibrated for each set of beam conditions using a suite of appropriate mineral standards and the calibration was verified using a range of secondary glass standards from the Max Planck Institute. Further, spot analysis of major oxides (semi-quantitative) of glass, phenocrysts of pyroxenes, spinel and manganese oxides were carried out on a few thin sections of partially and fully coated pumice by Energy Dispersive Spectrometer (EDS) attachment to JEOL SEM operating at voltage $20 \mathrm{kV}$ and beam current of $55 \mathrm{nA}$ at National Institute of Oceanography, Goa.

\section{Results}

Thin sections of partially and fully coated pumice were observed under polarizing microscope and images of mineral grains were photographed. The model percentage calculated using Image Focus 3.0 software, indicates that fully and partially coated pumice have an average of $\sim 3.1 \%$ and $\sim 1.2 \%$ of crystal phases respectively. Thin sections show presence of $>95 \%$ of glass with isolated or at times rare crystal clots in both fully and partially coated pumice.

The major element composition of partially and fully Fe-Mn oxide coated pumice clasts by XRF (Table 1), and glass (Table 2) and mineral grains by EPMA (Table 3), have been recalculated to a water-free (anhydrous) basis. Trace and rare earth element compositions of the partially and fully coated bulk pumice fragments determined by solution nebulisation ICP-MS are provided in Table 4 . Glass composition from the pumice (EPMA) with YTT, MTT and OTT and bulk major element data of both partially and fully coated pumice with MTT, OTT and HDT fiamme and welded tuff are presented in Table 5 and 6 respectively.

The raw EPMA analyses of glass from both coated and uncoated pumices give analytical totals $\sim 97 \%$, indicating that the CIOB pumice is relatively unhydrated. This compares well with the average total analyses $(n>100)$ of unaltered proximal glass from YTT pumice clasts from Sumatra (Smith and Pearce, unpublished data). EMPA data (Table 2) show that the leaching of pumice clasts 
with $6 \mathrm{~N} \mathrm{HCl}$ to remove the encrusting Fe-Mn oxide coating has caused no detectable change in the composition of the glass. The bulk sample major element composition (XRF) of partially $(\mathrm{n}=11)$ and fully $(n=4)$ coated pumice grains has $77.06 \pm 0.93 \%, 75.17 \pm 1.51 \% \quad \mathrm{SiO}_{2}$ and $13.02 \pm 0.23 \%$, $13.79 \pm 0.92 \% \mathrm{Al}_{2} \mathrm{O}_{3}$ (1 standard deviation, see Table 1 ) respectively.

The average composition of orthopyroxene from the partially coated pumice (determined by EPMA, see Table 3) has a composition $\mathrm{Mg}_{0.64} \mathrm{Fe}_{0.30} \mathrm{Ca}_{0.06}$ (enstatite). The EDS data of feldspar crystals from partially coated pumice suggest two generations of plagioclase; one with anorthite (An) content of 70 \pm 5 and the second type have $40 \pm 5$.

The average total Rare Earth Element ( $\mathrm{REE}$ ) contents of the partially and fully coated pumice are $119 \mathrm{ppm}$ and $128 \mathrm{ppm}$ respectively.

\section{Discussion}

The occurrence of fully Fe-Mn oxide coated pumice with partially coated and fresh/uncoated one at the sediment-water interface could be the result of the so-called "Brazil Nut Effect", where larger grains are kept at the sediment-water interface while smaller grains sink because of shaking/tectonic effects (Rosato et al., 1987). In addition to Brazil Nut Effect, bioturbation, benthic organisms and bottom water currents might have helped to keep the older pumice (Fe-Mn oxide coated) together with younger one (partially coated) on the sediment-water interface (Glasby, 1977; Piper and Fowler, 1980; McCave ,1988).

These pumice are mostly rounded to sub-rounded shape similar to the earlier observations of Pattan et al., (2008) which indicates their long transportation and abrasion. Earlier, Iyer and Karisiddaiah (1988) studied 48 pumices and more recently, Kalangutkar et al. (2011) analysed about 400 pumice clasts from $\mathrm{CIOB}$ and found that majority of them are of equant and oblate shape based on Zinggs shape diagram. Further, these pumice are highly vesicular, inter connected to each other and majority of these vesicles are elongated (60\%) and spherical (30\%) in nature (Kalangutkar et al., 2011). Therefore, shape and vesicularity of these pumice strongly support drift or transported origin for these pumice.

Both partially and fully coated pumice under microscope contain mineral grains up to $3 \%$ which is considerably less than that reported for the Toba Tuffs of 15-40\% (Chesner, 1998). Glass in the pumice is like a volcanic froth solidified with interconnecting vesicles of different shape and size. Some times glass has been stained by Fe-Mn oxide (dark yellowish colour), exhibit flow structure 
and few isolated plagioclase laths show alteration (Fig. 2). Few crystal clots are observed which are mostly hetero-cumulates of plagioclase and ortho-pyroxenes. Spinels are mostly associated with pyroxenes (Fig. 2.). Such an observation was not noticed earlier in pumice in the same basin which could be due to their younger age of 1883-Krakatau (Mudholkar and Fujii, 1995). Minerals observed in these pumice glass are tabular plagioclase feldspars, green coloured orthopyroxenes, dark black euhedral spinels and manganese oxides (Fig.2). These orthopyroxenes exhibit pleochrosim in the green to dull pink/brown colour. The mineral grains reported in the YTT, MTT and OTT are of quartz, sanidine, plagioclase, biotite and amphibole with minor minerals of magnetite, illmenite, allanite, zircon and orthopyroxens (Chesner, 1998).

The bulk sample major element composition (XRF) of partially and fully coated pumice grains has nearly similar content of $\mathrm{SiO}_{2}$ and $\mathrm{Al}_{2} \mathrm{O}_{3}$, (Table 1) and suggests a uniform, source for these pumice. Iyer and Sudhakar (1993) reported the partial composition $\left(\mathrm{SiO}_{2}\right.$ and $\left.\mathrm{Al}_{2} \mathrm{O}_{3}\right)$ of some pumices recovered from the $\mathrm{CIOB}$, and they speculated that these had an in-situ origin. Their analyses, with $\mathrm{SiO}_{2} \sim 62 \%$, differ significantly from the pumice data here, and thus the origins of these two sets of pumices are considered to be different. Scatter plots of few major elements from both partially and fully coated pumice exhibit similar behaviour and a single trend line is observed probably suggesting similar source (Fig. 3). Both the bulk XRF analyses and EPMA glass data show that both partially and fully coated pumice have high silica and total alkali contents making them rhyolitic in composition (see Tables $1 \&$ 2), and the concentrations of $\mathrm{Fe}, \mathrm{Ca}$, $\mathrm{Ti}$ and $\mathrm{Mg}$ are all within the typical range for rhyolites. There are differences in the composition of bulk pumice determined by XRF and average glass analyses by EPMA because of the presence of phenocrysts of feldspars, pyroxene and biotite within the bulk samples (see Pearce et al., 2002; 2004 for discussion).

The average composition of orthopyroxene from the partially coated pumice (Table 3) has a composition $\mathrm{Mg}_{0.64} \mathrm{Fe}_{0.30} \mathrm{Ca}_{0.06}$ (enstatite). This is nearly same to orthopyroxenes from the 1883 eruption of Krakatau, with $\mathrm{Mg}_{0.72} \mathrm{Fe}_{0.25} \mathrm{Ca}_{0.02}$ (Mudholkar and Fujii, 1995) and from the HDT, with $\mathrm{Mg}_{0.62} \mathrm{Fe}_{0.36} \mathrm{Ca}_{0.05}$. Orthopyroxenes from the CIOB pumices are however notably different from orthopyroxenese in the rhyolitic eruptives from the Toba Caldera (viz. YTT- $\mathrm{Mg}_{0.44} \mathrm{Fe}_{0.54} \mathrm{Ca}_{0.02}$, MTT- $\mathrm{Mg}_{0.33} \mathrm{Fe}_{0.65} \mathrm{Ca}_{0.03}$ and OTT- $\left.\mathrm{Mg}_{0.39} \mathrm{Fe}_{0.58} \mathrm{Ca}_{0.03}\right)$ which are all ferrosilite with lower $\mathrm{Mg}$ and $\mathrm{Ca}$ (Chesner, 1998; Fig. 4) and this rules out a correlation with any of the $<0.8 \mathrm{Ma}$, voluminous Toba rhyolitic eruptions.

The fully, partially and uncoated pumice analysed by Pattan et al., (2008), in general, have nearly similar major, trace and REE compositions, and this implies that they were sourced from either a 
single large event or multiple events from a compositionally similar source. A scenario involving multiple events allows for the accretion of different thicknesses of Fe-Mn oxide coating over different periods of time. The pumice clasts from the CIOB are also mineralogically and compositionally similar to the products of the Toba caldera, which has arguably been the source of much pumiceous material in the Indian Ocean over the last 1.2 Ma, and possibly longer. Despite the enormous volume of pyroclastic material released and dispersed during these Toba eruptions, however, there is little or no chemical data for distal Middle Toba Tuff (MTT), Oldest Toba Tuff (OTT) and Haranggoal Dacite Tuff (HDT). Published MTT, OTT and HDT analyses (Chesner and Rose, 1991; Chesner, 1998) come from bulk samples of proximal crystal-rich ignimbrites, making comparisons with distal materials such as pumice and glass (which have fewer crystals) is potentially difficult. In contrast, bulk data for the YTT has been published, and fresh material is plentiful. For comparisons therefore, whole rock geochemistry of drilled fiamme and welded tuffs of MTT, OTT and HDT are used (Chesner, 1998; Chesner and Luhr, 2010) and these analyses are presented in Table 6. However, when comparing bulk proximal and distal pyroclastic materials, by using a combination of whole rock/tephra and pumice analyses caution needs to be exercised because of the physical difference in the materials being compared (cf. Pearce et al., 2002; 2004).

Comparison of the major element bulk composition (by XRF) of both partially and fully coated pumice from the CIOB show similar composition (Table 1), but these differ from Toba eruptive material such as fiamme and welded tuff of MTT, OTT and HDT (Table 6; Chesner, 1998; Chesner and Luhr, 2010). HDT samples have relatively low $\mathrm{SiO}_{2}$ and $\mathrm{Na}_{2} \mathrm{O}$ while the remaining oxides $\left(\mathrm{TiO}_{2}\right.$, $\mathrm{Al}_{2} \mathrm{O}_{3}, \mathrm{Fe}_{2} \mathrm{O}_{3}, \mathrm{MgO}$ and $\mathrm{K}_{2} \mathrm{O}$ ) are all enriched compared to CIOB coated pumice. Similarly analyses from the MTT, and OTT fiamme and welded tuff are also different from the present study.

Uncoated pumice clasts from the CIOB have already been attributed to $\sim 74$ ka YTT eruption (Pattan et al., 2008) even though these are depleted in $\mathrm{K}_{2} \mathrm{O}$ compared to proximal materials (CIOB pumice 2.59\%; YTT caldera pumice from Sumatra 4.97\%). Alkali exchange ( $\mathrm{Na} / \mathrm{K}$ exchange) is a common phenomenon which can affect volcanic glass after deposition. Experimental studies of seawaterrhyolite interaction (Shiraki et al.,1987) show that $\mathrm{Na}, \mathrm{Mg}$ and $\mathrm{Cl}$ are removed from seawater by the rhyolite, and $\mathrm{K}$ is released from the rhyolite. Thus, residence on the ocean floor of volcanic glass would result in a gradual decrease in the $\mathrm{K} / \mathrm{Na}$ ratio, and increases in $\mathrm{Na}, \mathrm{Mg}$ and $\mathrm{Cl}$ in the glass with time. Proximal YTT glass (Smith and Pearce unpublished data) has higher $\mathrm{K}_{2} \mathrm{O}$, and lower $\mathrm{Na}_{2} \mathrm{O}$, $\mathrm{MgO}$ and $\mathrm{Cl}$ than glass from the uncoated pumice, and this is consistent with the expected interactions between rhyolite and seawater (Shiraki et al., 1987). A negative correlation between 
$\mathrm{Na}_{2} \mathrm{O}$ and $\mathrm{K}_{2} \mathrm{O}$ is also observed in the glass from all the pumice clasts, again indicative of alkali exchange (and this is illustrated for one sample in Fig. 5). It is interesting to note that the $\mathrm{K}_{2} \mathrm{O}$ content of glasses in Layers A, C and E, from ODP Leg 758 (correlated with YTT, MTT and OTT, see Westgate et al. 1998) are not depleted compared to proximal deposits, resulting from their limited time in contact with seawater. In contrast, pumice clasts resident at the sediment/water interface, becoming slowly encrusted by Fe-Mn oxides, are in direct contact with seawater for many tens to hundreds of ka, allowing opportunity for alkali exchange and potential loss of $\mathrm{K}_{2} \mathrm{O}$ from the glass. Because of possible compositional changes to glass during residence on the sea floor, major element comparisons with potential source materials require careful consideration.

The glass phase from of the partially coated pumice was analysed (by EPMA) and compared with glass from YTT, MTT and OTT (see Table 5). It is evident that glass from the coated pumice is also distinctly different from glass in the YTT, MTT and OTT tephra deposits. There are significant differences between the $\mathrm{K}_{2} \mathrm{O}$ and $\mathrm{Na}_{2} \mathrm{O}$ contents of the CIOB pumice and glass from YTT, MTT or OTT, with the CIOB samples all having lower $\mathrm{K}_{2} \mathrm{O}$ contents and higher $\mathrm{Na}_{2} \mathrm{O}$ (Table 5). Again, with these older (partially coated) pumice clasts, seawater alteration may have modified their compositions during longer residence time on the ocean floor. Thus while the compositions of the glass in the CIOB pumice clasts differ from material erupted from the Toba caldera, it is possible that difference may result from alteration and alkali-exchange of the glass during extended contact with seawater. The glass composition of partially coated pumice (AAS-26-D14) is close to the glass shards from ash layer "I" in the ODP site 758B-6H (Dehn et al., 1991) which has an age of 4Ma old (Table 2). However, $\mathrm{Na}$ and $\mathrm{K}$ content of this partially coated pumice are low mainly due to leaching and interaction with seawater on the seafloor.

The EDS data of feldspar crystals from partially coated pumice suggest two generations of plagioclase; one with anorthite (An ) content of $70 \pm 5$ and the second type have $40 \pm 5$ Fully coated pumice has also two generations of plagioclase but with low content of An of $45 \pm 5$ and $30 \pm 5$ and other sample has more of albite than anorthite with An content of $40 \pm 5$ and $25 \pm 5$. Spinel in partially coated pumice is of magnetite $\left(\mathrm{FeO}-83.1 \%, \mathrm{TiO}_{2}-10.6 \%\right)$ where as, fully coated pumice have both Ilmenite $\left(\mathrm{TiO}_{2}-41.15 \% ; \mathrm{FeO}-53.61 \%\right)$ and magnetite (Fe-87.15\%). Ortho-pyroxene ( $\mathrm{MgO}-23.8 \%$; FeO-17.2\%) is present in both types of pumice. This suggests that there appears to be minor difference in mineralogy between partially and fully coated pumice. There is presence of $\mathrm{Mn}$ oxide precipitation in the form of botryoids (Fig. 2) commonly present as a todorokite phase with 
high $\mathrm{MnO}$ content of $32 \%, \mathrm{FeO}-6 \%$, NiO $-1.6 \%$ and $\mathrm{CuO}-0.9 \%$ within the vesicle (Fig.2). Some times $\mathrm{MnO}$ content of these botryoids reaches up to $58 \%$.

Further insight into the origins of the coated pumice can be obtained from trace element data. However, in making comparisons, it must be remembered that analyses have been performed on different materials as parts of different studies

The average total Rare Earth Element ( $\left.\sum \mathrm{REE}\right)$ contents of the partially and fully coated pumice are $119 \mathrm{ppm}$ and $128 \mathrm{ppm}$ respectively. The REE content of these pumice grains is very similar to each other and as well as that of the uncoated pumice from the CIOB (121 ppm, Pattan et al., 2008), These $\sum$ REE contents and profiles are similar to material from the Toba Caldera; to glass shards of YTT origin from different locations such as the CIOB, Peninsular India, South China Sea, Arabian Sea; and to Layers A, C and E from ODP-758 (Westgate et al., 1998; Song et al., 2000; Pattan et al., 2001; 2002). An ash layer was described from ODP 758 at $\sim 8.2 \mathrm{Ma}$ (Late Miocene) which also has similar REE concentrations ( $\sum \mathrm{REE} 123 \mathrm{ppm}$ ) to the coated pumices, and this has been speculated to be of Toba origin (Padmakumari and Ahmad, 2004). The chondrite-normalized REE profiles of coated and uncoated pumice from the CIOB (Fig.6) and glass shards of YTT, MTT, OTT and the $\sim 8.2 \mathrm{Ma}$ ash are all very similar, with strong light REE enrichment ( $\mathrm{La} \sim 100$ times chondrite), pronounced negative Eu-anomalies, and a generally flat heavy REE profile at 10 to 20 times chondrite (see Fig. 6 a \& b). These features are typical of evolved rhyolitic magmas formed by fractional crystallisation involving the extraction of feldspar. Chondrite-normalized REE pattern of these coated and uncoated pumices, YTT, MTT and OTT all fall within the field occupied by rhyolitic rocks from Sumatra (Fig. 6c; Ikeda et al., 1980; Masuda 1980). Figure 6a shows the CIOB pumice clasts plotted on the $\mathrm{Y}-\mathrm{Nb}$ tectonomagmatic discrimination diagram for rhyolites/granites of Winchester and Floyd (1977). Other tectonomagmatic discrimination diagrams exist but many include $\mathrm{Rb}$ on one axis, and these are not used here because it is possible that some alteration of the $\mathrm{Rb}$ content of these samples may have taken place by reaction with sea water (cf. $\mathrm{K}_{2} \mathrm{O}$, see above). The Y-Nb diagram indicates a "volcanic arc" source for the pumice grains from the CIOB (Fig.7a). Similarly, in the Ti-Zr-Y ternary discrimination diagram of Yamamoto et al., (1986), pumice fragments from this study and altered ash layers of Miocene age from the CIOB lie in the compositional field of "arc related rhyolite" (Fig. 7b). The partially and fully coated pumice fragments are compositionally different (bulk composition, glass and mineral chemistry) from YTT (0.074 Ma), MTT (0.5 Ma), OTT (0.8 Ma) and HDT (1.2 Ma) indicative of a different source for these samples. The partial to full coating by Fe-Mn oxide on the CIOB pumices, also implies an 
extended period of accretion ( $>>1 \mathrm{Ma}$ ) suggesting that these may predate the onset of activity from the Toba caldera. Martin-Barajas and Lallier-Verges, (1993) described four altered tephra layers of 10-35 $\mathrm{mm}$ thick occurring at depths of up to $7 \mathrm{~m}$ below the surface in the CIOB, and suggested a source for these from Sumatra, these being mostly of Late Miocene age. They however display much higher REE contents than the pumices from the CIOB, with a generally steep REE patterns and positive Ce anomalies (Martin Barajas and Lallier-Verges, 1993. Based on the thickness of partial to complete Fe-Mn oxide coatings on the CIOB pumice clasts, these seem likely to be between Late Miocene and Early Pleistocene in age, and sources from Indonesian Arc. They are not from the present day Toba caldera, but based on their similarity of distribution with uncoated YTT pumice clasts in the CIOB, these coated pumices probably result from similar, but older, large-volume rhyolite magmatism in Indonesian Arc.

\section{Dispersal of pumice and conclusions}

The dispersal of floating pumice by ocean surface currents is an effective mechanism for transport over a great distance. Frick and Kent (1984) reported the 1883- Krakatau pumice occurring along the coasts of Madagascar, South Africa and many other Indian Ocean coasts. Recently, Pattan et al. (2008) described the dispersal of YTT pumice. They suggested that YTT pumice, after reaching the northern Indian Ocean, was carried along the South Java Current which becomes stronger on merging with the Indonesian Through Flow as water enters from the Pacific Ocean. This Indonesian Through Flow then joins the South Equatorial Currents and intensifies its movement westward (Gorden et al., 1997) and, by this route, carried YTT pumice clasts from Sumatra into the CIOB. Similarly, based on circulation and their distribution, the partially and fully coated pumice fragments are likely to have been transported by the same route into the CIOB, but their source could have been either Sumatra or Java (and further east). The tectonic setting indicated by the minor and trace element composition of the CIOB pumices indicates that they are not in-situ (ocean ridge or intraplate) in origin, as had been suggested earlier, and they have an island arc origin (Indonesia). The

partially and fully coated pumice fragments from the CIOB studied here, overlap in distribution with uncoated pumice previously identified as YTT, and these occur over an area of $\sim 600,000 \mathrm{~km}^{2}$, and this suggests they are associated with a significant period of rhyolitic volcanism.

This pumice field is situated $\sim 3000 \mathrm{~km} \mathrm{SW}$ of the Toba caldera. Their calc-alkaline composition indicates a volcanic arc source. Their major and trace element composition is similar to material from the Toba caldera, but mineral chemistry rules out Toba as the source. There is slight variation in mineralogy among the partially and fully coated pumice. The partial to full coating with Fe-Mn 
oxide suggests an age $>1 \mathrm{Ma}$, older than most of the products of the Toba caldera, but compositionally the pumice do not correlate with ash layers of Late Miocene age which have also been described from the CIOB. Their most likely source is the Indonesian arc and they are probably between Late Miocene and Early Pleistocene in age, but as yet their source remains unidentified.

\section{Acknowledgements}

The authors (JNP, GP and AVM) are thankful to the Director, NIO, Goa, for the encouragement to carry out the work. Authors are grateful to Prof. Craig Chesner for the suggestions and providing his unpublished data of MTT and OTT fiamme. Both the reviewers are thanked for their constructive comments and suggestions which helped to improve the quality of our manuscript. Mr. Andy Brown at Aberystwyth and Mr. P. Milind Raj at Goa are thanked for preparing the samples of pumice for ICP-MS analysis. Thanks are due to Mr. B. Vijay Kumar for providing pumice samples from the repository, Mr Moraes, C for XRF analysis, Ms. Samina B. for EDS analysis and Mr. R.Uchil for drafting the figures,. This is NIO Contribution NO.....

\section{References}

Allen, S.R, Fiske, R.S and Tamura, Y., 2010. Effects of water depth on pumice formation in submarine domes at Sumisu, Izu-Basin arc, western Pacific. Geology 38 (5), 391-994.

Banakar, V. K., 1990. Uranium-thorium isotopes and transition metal fluxes in two oriented manganese nodules from the Central Indian Basin, implications for nodule turnover. Marine Geology 95, 71-76.

Banakar, V. K., Gupta, S.M., Padmavati, V.K., 1991. Abyssal sediment erosion in the Central Indian Basin, evidence from radiochemical and radiolarian studies. Marine Geology 96, 167-173.

Chesner, C.A., Rose, W.I ., 1991. Stratigraphy of the Toba Tuffs and the evolution of the Toba caldera complex, Sumatra, Indonesia. Bulletin of Volcanology 53, 343-356.

Chesner, C. A., 1998. Petrogenesis of the Toba Tuffs, Sumatra, Indonesia. Journal of Petrology 39 (3), 397-438.

Chesner, C. A., Luhr, J. F., 2010. A melt inclusion study of the Toba Tuffs, Sumatra, Indonesia. Journal of Volcanology \& Geothermal Research , dio. 1016/j.j volgeores 2010.06.001.

Camus, G., Gourgaud, a., Vincent, P.M., 1987. Petrologic evolution of Krakatau (Indonesia), Implications for a future activity. J. Voloconology \& Geothermal Research 33, 299-316.

Dehn, J., Farrel, J.W., Schmincke, H.-U., 1991. Neogene tephrochronology- from Site 758 on northern Ninetyeast Ridge, Indonesian arc volcanism of the past $5 \mathrm{Ma}$, Proceedings of the Ocean Drilling Program, Scientific results. 121, 273-295. 
de Vantie, L.M., 1992. Rafting of tropical marine organisms on buoyant corolla. Marine Ecology Progress Series 86, 301-302.

Frick, C., Kent, L.E., 1984. Drift pumice in the Indian and South Atlantic Oceans. Transactions of Geological Society of South Africa 87, 19-33.

Glasby, G.P., 1977. Why manganese nodules remain at sediment-water interface. New Zealand J. Science 20, 187-190.

Gorden, A.L., Ma S, Olson, D.B., Hacker, P., Ffield, A., Talley, L.D., Wilson, D., Baringer, P., 1997. Advection and diffusion of Indonesian through flow water within the Indian Ocean South Equatorial Current. Geophysical Research Letters 24(21), 2573-2576.

Hedervari, P., 1982. A possible submarine volcano near the Central part of Ninety-East Ridge, Indian Ocean. Journal of Volcanology and Geothermal Research 13, 199-211.

Ikeda, T., Nishimura, S., Yokoyama, T., Hehuwat, F., 1980. Trace element variations in volcanic rocks in the Sunda Arc regions, Indonesia. In, S. Nishimura (Editor), Phys. Geol. Indonesian Island Arcs, Kyoto Univ. 97-108.

Iyer, S.D., Karisiddaiah, S. M., 1988. Morphology and petrography of pumice from the Central Indian Ocean Basin. Indian Journal of Marine Sciences 17, 333-334.

Iyer, S.D., Sudhakar, M., 1993. Co-existence of pumice and manganese nodule fields - evidence for submarine silicic volcanism in the Central Indian Basin. Deep Sea Research I 40(5), 11231129.

Jokiel, P.L., Cox, E.F., 2003. Drift pumice at Christmas Island and Hawaii, evidence of oceanic dispersal patterns. Marine Geology 202, 121-133.

Kalangutkar, N.G., Iyer, S. D., Ilangovan, D. 2011. Physical properties, morphology and petrological characteristics of pumices from the Central Indian Ocean Basin. Acta Geological Sinica (English edition) 85, 826-839.

Martin-Barajas, A., Lallier-Vergès, E., 1993. Ash layers and pumice in the Central Indian Basin, relationship to the formation of manganese nodules. Marine Geology 115, 307-329.

Masuda, Y., 1980. Trace element abundances in the ignimbrites from Sumatra and Sulawesi

islands, Indonesia . In, S. Nishimura (Editor), Phys. Geol. Indonesian Island Arcs,

Kyoto Univ. 97-108.iM .

McCave, I.N., 1988. Biological pumping upward of the coarse fraction of deep-sea sediments. Sedimentary Petrology 58, 148-158.

Mudholkar, A.V., Fujii, T.,1995. Fresh pumice from the Central Indian Basin, a Krakatau 1883 signature. Marine Geology 125, 143-151.

Padmakumari, V.M., Ahmad, S.M., 2004. Ash layer at $~ 8$ Ma in ODP site 758 from the Bay of Bengal, evidence from $\mathrm{Sr}, \mathrm{Nd}$ isotopic composition and rare earth elements. Current Science 86(9), 1323-1325.

Pattan, J.N., Shane, P., Banakar, V.K., 1999. New occurrence of Youngest Toba Tuff in abyssal sediments of the Central Indian Ocean Basin. Marine Geology 155, 243-248. 
Pattan, J.N., Shane, P., Pearce, N.J.G., Banakar, V.K, Parthiban, G., 2001. An occurrence of 74 ka Youngest Toba tephra from western continental margin of India. Current Science 80, 13221326.

Pattan, J.N., Pearce, N.J.G., Banakar V.K., Parthiban, G., 2002. Origin of ash in the Central Indian Ocean Basin and its implications for the volume estimate of the 74,000 years BP Youngest Toba eruption. Current Science 84, 889-893.

Pattan, J.N., Mudholkar, A.V., Jai Sankar, S., Ilangovan, D., 2008. Drift pumice in the Central Indian Ocean Basin, Geochemical evidence. Deep Sea Research I 55, 369-378.

Pattan, J.N., Prasad, M.S., Babu, E.V.S.S.K. 2010. Correlation of the Oldest Toba Tuff to sediments I the Central Indian Ocean Basin., J. Earth System Sciences 119, 531-539.

Pearce, N.J.G., Eastwood, W.J., Westgate, J.A., Perkins, W.T,. 2002. Trace-element composition of single glass shards in distal Minoan tephra from SW Turkey. Journal of the Geological Society of London 159, 545-556.

Pearce, N.J.G., Westgate, J.A., Perkins, W.T., Preece, S.J., 2004. The application of ICP-MS methods to tephrochronological problems. Applied Geochemistry 19, 289-322.

Piper, D.Z., Fowler, B. 1980. New constraints on the maintenance of manganese nodules at the sediment surface. Nature 286, 880-883.

Rosato, A., Strandberg, K.J., Prinz, F., Swendsen, R.H., 1987. Why the brazil nuts are on top, size segregation of particulate matter by shaking. Physical Review Letters 58, 1038-1040.

Shiraki, R., Sakai, H., Endoh, M., Kishima, N., 1987. Experimental studies on rhyolite- and andesiteseawater interactions at $300^{\circ} \mathrm{C}$ and 1000 bars. Geochemical Journal 21, 139-148.

Song, S.R., Chen, H., Lee, M.Y., Yang, T.F., Iizuka, Y., Wei, .KY., 2000. Newly discovered eastern dispersal of the Youngest Toba Tuff. Marine Geology 167, 303-312.

USGS, 2006. http,//minerals.cr.usges.gov/geo_chem_stand.

Whitham, A.G. and Sparks, R.S.J. 1986. Pumice. Bulletin of Volcanology 48, 209-223.

Winchester, J.A., Floyd, P.A., 1977. Geochemical discrimination of different magma series and their differentiation products using immobile elements. Chemical Geology 20, 325-343.

Westgate, J.A., Shane, P.A.R., Pearce, N.J.G., Perkins, W.T., Korisettar, R., Chesner, C.A., Williams, M.A., Acharyya, S.K., 1998. All Toba tephra occurrences across peninsular India belong to the 75,000 yr B.P eruption. Quaternary Research 50, 107-112.

Yamamoto, K., Sugisaki, R., Arai, F., 1986. Chemical aspects of alteration of acidic tuffs and their application to siliceous deposits. Chemical Geology 55, 61-76. 


\section{Captions to the tables}

Table 1.Major element composition (wt \%), determined by XRF of pumice, partially and fully coated with ferro-manganese oxide from the Central Indian Ocean Basin along with the determined and certified concentrations for the reference material JR-1.

Table 2. Average electron microprobe analysis (EPMA) of glass from selected pumice samples.

Table 3.Electron microprobe analysis of ortho-pyroxene from partially coated pumice and compared with YTT, MTT, OTT, HDT and 1883-Krakatau.

Table 4.Trace-element composition (ppm) of pumice partially and fully coated with Fe-Mn oxide from the Central Indian Ocean Basin, determined by ICP-MS.

Table 5. Comparison of glass composition (EPMA) of partially coated pumice with YTT, MTT and OTT.

Table 6. Comparison of major element composition (average) of partially and fully coated pumice from the CIOB, along with MTT, OTT and HDT fiamme and welded tuff from Sumatra. 
Table 1

\begin{tabular}{|c|c|c|c|c|c|c|c|c|c|c|c|c|c|c|c|c|c|c|c|c|c|}
\hline \multirow[b]{2}{*}{ Wt $\%$} & \multirow[b]{2}{*}{$\begin{array}{c}\text { JR-1 } \\
\text { (Analysed } \\
\text { ) }\end{array}$} & \multirow[b]{2}{*}{$\begin{array}{c}\text { JR-1 } \\
\text { (Reported } \\
\text { ) }\end{array}$} & \multicolumn{13}{|c|}{ Partially coated pumice } & \multicolumn{6}{|c|}{ Fully coated pumice } \\
\hline & & & $\begin{array}{c}\text { AAS-22/ } \\
\text { 10-D }\end{array}$ & $\begin{array}{c}\text { AAS-22/ } \\
10\end{array}$ & $\mid \begin{array}{c}\text { AAS-22/ } \\
11\end{array}$ & $\begin{array}{c}\text { AAS-22/ } \\
14\end{array}$ & $\begin{array}{c}\text { AAS-22/ } \\
9\end{array}$ & $\begin{array}{c}\text { AAS-26/ } \\
14\end{array}$ & $\begin{array}{c}\text { AAS-26/ } \\
38\end{array}$ & $\mid \begin{array}{c}\text { SK-23/ } \\
269 \mathrm{~F}\end{array}$ & $\begin{array}{l}\text { SS-16/ } \\
833 C\end{array}$ & $\begin{array}{l}\mathrm{F}-2 / \\
78 \mathrm{D}\end{array}$ & $\begin{array}{l}F-2 / \\
71 F\end{array}$ & $\begin{array}{l}\text { Mean } \\
(\mathrm{n}=11)\end{array}$ & $\begin{array}{l}\text { Std } \\
\text { dev. }\end{array}$ & $\begin{array}{l}\text { AAS- } \\
22 / \\
\text { D-11 }\end{array}$ & $\begin{array}{c}\text { AAS- } \\
2 / \\
\text { D-15 }\end{array}$ & $\begin{array}{c}\text { AAS- } \\
22 / \\
\text { D-17 }\end{array}$ & $\begin{array}{c}\text { AAS-22/ } \\
\text { D-19 }\end{array}$ & $\begin{array}{c}\text { Mea } \\
n \\
(n=4)\end{array}$ & $\begin{array}{l}\text { Std.De } \\
\text { v }\end{array}$ \\
\hline$\overline{\mathrm{SiO}_{2}}$ & 75.40 & 75.41 & 76.81 & 77.35 & 77.01 & 78.41 & 78.95 & 76.35 & 77.18 & 75.93 & 76.20 & 77.15 & 76.28 & 77.06 & 0.93 & 77.31 & 74.41 & 75.12 & 73.86 & 75.17 & 1.51 \\
\hline $\mathrm{Al}_{2} \mathrm{O}_{3}$ & 12.87 & 12.89 & 13.04 & 13.09 & 13.09 & 13.25 & 13.03 & 13.19 & 13.08 & 13.09 & 13.09 & 12.36 & 12.96 & 13.02 & 0.23 & 12.63 & 13.46 & 14.55 & 14.52 & 13.79 & 0.92 \\
\hline $\mathrm{Fe}_{2} \mathrm{O}_{3}$ & 0.96 & 0.96 & 2.07 & 1.84 & 2.20 & 2.08 & 1.05 & 2.14 & 1.37 & 3.20 & 1.42 & 1.81 & 1.79 & 1.91 & 0.56 & 1.84 & 2.63 & 1.34 & 2.20 & 2.00 & 0.55 \\
\hline $\mathrm{MnO}$ & 0.10 & 0.10 & 0.081 & 0.081 & 0.081 & 0.071 & 0.051 & 0.102 & 0.061 & 0.487 & 0.305 & 0.356 & 0.594 & 0.21 & \begin{tabular}{|l|}
0.20 \\
\end{tabular} & 0.06 & 0.10 & 0.08 & 0.08 & 0.08 & 0.02 \\
\hline $\mathrm{MgO}$ & 0.37 & 0.09 & 0.22 & 0.29 & 0.40 & 0.31 & 0.26 & 0.35 & 1.07 & 0.49 & 0.31 & 0.36 & 0.59 & 0.42 & 0.24 & 0.47 & 0.66 & 0.28 & 0.39 & 0.45 & 0.16 \\
\hline $\mathrm{CaO}$ & 0.61 & 0.63 & 1.40 & 1.14 & 1.41 & 1.35 & 0.86 & 1.39 & 0.95 & 2.12 & 1.19 & 2.21 & 1.51 & 1.41 & 0.42 & 1.02 & 1.16 & 1.20 & 1.09 & 1.18 & 0.08 \\
\hline $\mathrm{Na}_{2} \mathrm{O}$ & 4.10 & 4.10 & 3.39 & 2.97 & 2.97 & 2.68 & 2.44 & 3.64 & 2.85 & 2.72 & 3.89 & 2.89 & 3.45 & 3.08 & 0.45 & 3.28 & 3.80 & 3.50 & 3.49 & 3.54 & 0.21 \\
\hline $\mathrm{K}_{2} \mathrm{O}$ & 4.40 & 4.41 & 2.69 & 2.79 & 2.46 & 1.46 & 3.01 & 2.39 & 3.04 & 1.31 & 3.30 & 2.54 & 2.44 & 2.49 & 0.62 & 3.00 & 3.26 & 3.70 & 4.00 & 3.49 & 0.45 \\
\hline $\mathrm{TiO}_{2}$ & 0.11 & 0.10 & 0.26 & 0.40 & 0.35 & 0.35 & 0.30 & 0.40 & 0.39 & 0.60 & 0.25 & 0.315 & \begin{tabular}{|l|l}
0.34 \\
\end{tabular} & 0.36 & 0.09 & 0.32 & 0.48 & 0.19 & 0.31 & 0.32 & 0.12 \\
\hline$\overline{\mathrm{P}_{2} \mathrm{O}_{5}}$ & 0.02 & 0.02 & 0.03 & 0.05 & 0.04 & 0.05 & 0.04 & 0.05 & 0.03 & 0.06 & 0.04 & 0.03 & 0.04 & 0.04 & 0.01 & 0.07 & 0.07 & 0.04 & 0.04 & 0.05 & 0.02 \\
\hline
\end{tabular}

Analyses normalized to $100 \%$ on water free basis with all $\mathrm{Fe}$ as $\mathrm{Fe}_{2} \mathrm{O}_{3}$. Std dev. - standard deviation. 
Table 2.

\begin{tabular}{|c|c|c|c|c|c|c|c|c|c|c|c|c|}
\hline Sample & Pyroxi & l YTT, & & & AS-26- & & & & & S-26-I & & \\
\hline Material & & & $\mathrm{Co}$ & ted & $\begin{array}{l}\text { Coat } \\
\text { Lea }\end{array}$ & & Bulk & Co & & $\begin{array}{l}\text { Coa } \\
\text { Lea }\end{array}$ & & Bulk \\
\hline Analysis (n) & EPM & $>100)$ & EPM & A(17) & EPM & (20) & XRF & & PMA & $21 \& 9$ & & $\mathrm{XRF}$ \\
\hline & Avg & S.D. & Avg & S.D. & Avg & S.D. & Avg & Avg & S.D. & Avg & S.D. & Avg \\
\hline $\mathrm{SiO}_{2}$ & 77.23 & 0.36 & 74.40 & 0.44 & 74.42 & 0.35 & 76.39 & 78.17 & 0.26 & 77.78 & 0.72 & 77.04 \\
\hline $\mathrm{TiO}_{2}$ & 0.06 & 0.03 & 0.32 & 0.03 & 0.31 & 0.04 & 0.40 & 0.15 & 0.03 & 0.18 & 0.02 & 0.35 \\
\hline $\mathrm{Al}_{2} \mathrm{O}_{3}$ & 12.54 & 0.20 & 13.83 & 0.17 & 13.84 & 0.17 & 13.20 & 12.71 & 0.14 & 12.73 & 0.17 & 13.09 \\
\hline $\mathrm{FeO}_{\mathrm{t}}$ & 0.84 & 0.12 & 1.54 & 0.12 & 1.54 & 0.09 & 2.14 & 1.07 & 0.09 & 1.18 & 0.35 & 2.20 \\
\hline $\mathrm{MnO}$ & 0.07 & 0.05 & 0.11 & 0.04 & 0.09 & 0.05 & 0.10 & 0.12 & 0.04 & 0.09 & 0.05 & 0.08 \\
\hline $\mathrm{MgO}$ & 0.05 & 0.02 & 0.30 & 0.03 & 0.32 & 0.03 & 0.35 & 0.25 & 0.02 & 0.35 & 0.34 & 0.40 \\
\hline $\mathrm{CaO}$ & 0.78 & 0.11 & 1.23 & 0.08 & 1.25 & 0.07 & 1.39 & 1.55 & 0.07 & 1.61 & 0.13 & 1.41 \\
\hline $\mathrm{Na}_{2} \mathrm{O}$ & 3.09 & 0.17 & 5.14 & 0.14 & 5.10 & 0.12 & 3.64 & 4.75 & 0.19 & 4.88 & 0.14 & 2.97 \\
\hline $\mathrm{K}_{2} \mathrm{O}$ & 5.20 & 0.14 & 2.90 & 0.09 & 2.90 & 0.05 & 2.39 & 1.11 & 0.04 & 1.07 & 0.06 & 2.46 \\
\hline $\mathrm{Cl}$ & 0.13 & 0.03 & 0.24 & 0.01 & 0.23 & 0.02 & nd & 0.13 & 0.01 & 0.13 & 0.01 & nd \\
\hline Total* & 97.59 & 1.25 & 96.63 & 0.61 & 96.81 & 0.49 & 99.99 & 98.19 & 1.50 & 98.60 & 0.48 & 99.60 \\
\hline $\mathrm{H}_{2} \mathrm{O}$ diff. & 2.41 & & 3.37 & & 3.19 & & 0.01 & 1.81 & & 1.40 & & 0.40 \\
\hline
\end{tabular}

All concentrations in wt $\%$ and normalized to $100 \% . n$ - Number of analyses per sample.

Analyses of Proximal YTT, Sumatra are from Smith and Pearce (unpublished). Total* - Average of raw analyses.

Coated indicates presence of Fe-Mn coating. Coated \& leached indicates samples were treated with $6 \mathrm{~N} \mathrm{HCl}$ to remove Fe-Mn coating.

$\mathrm{FeO}_{\mathrm{t}}-$ All Fe calculated as $\mathrm{FeO}$, nd - not determined. $\mathrm{H}_{2} \mathrm{O}$ diff- (100-total) 
Table 3

\begin{tabular}{|c|c|c|c|c|c|c|c|c|c|}
\hline$\underline{\mathrm{AAS}-22 / \mathrm{D}-11}$ & $\mathrm{SiO}_{2}$ & $\mathrm{TiO}_{2}$ & $\mathrm{Al}_{2} \mathrm{O}_{3}$ & $\mathrm{FeO}$ & $\mathrm{MnO}$ & $\mathrm{MgO}$ & $\mathrm{CaO}$ & $\mathrm{Na}_{2} \mathrm{O}$ & $\mathrm{K}_{2} \mathrm{O}$ \\
\hline 1 & 53.70 & 0.48 & 2.99 & 18.36 & 1.66 & 19.01 & 3.23 & 0.55 & 0.02 \\
\hline 2 & 54.66 & 0.32 & 2.29 & 18.51 & 1.66 & 19.77 & 2.40 & 0.40 & 0.01 \\
\hline 3 & 55.29 & 0.34 & 2.40 & 18.40 & 1.73 & 19.21 & 2.07 & 0.52 & 0.04 \\
\hline 4 & 53.66 & 0.48 & 3.08 & 18.68 & 1.64 & 19.07 & 2.86 & 0.54 & 0.01 \\
\hline 5 & 54.31 & 0.40 & 2.81 & 18.63 & 1.70 & 19.26 & 2.43 & 0.44 & 0.01 \\
\hline 6 & 54.79 & 0.29 & 2.01 & 18.64 & 1.72 & 20.21 & 2.00 & 0.34 & 0.01 \\
\hline 7 & 54.03 & 0.44 & 2.99 & 18.11 & 1.69 & 19.17 & 2.99 & 0.56 & 0.02 \\
\hline 8 & 53.40 & 0.53 & 3.39 & 17.91 & 1.61 & 18.72 & 3.77 & 0.65 & 0.03 \\
\hline 9 & 53.92 & 0.44 & 3.03 & 18.20 & 1.58 & 19.11 & 3.15 & 0.57 & 0.01 \\
\hline 10 & 54.73 & 0.29 & 1.93 & 18.91 & 1.62 & 20.07 & 2.11 & 0.34 & 0.01 \\
\hline 11 & 55.23 & 0.33 & 1.98 & 17.94 & 1.58 & 20.26 & 2.31 & 0.37 & 0.01 \\
\hline 12 & 55.10 & 0.28 & 2.12 & 18.06 & 1.67 & 20.30 & 2.07 & 0.40 & 0.01 \\
\hline 13 & 53.54 & 0.43 & 2.85 & 18.66 & 1.70 & 19.48 & 2.80 & 0.52 & 0.03 \\
\hline 14 & 54.69 & 0.34 & 2.21 & 18.99 & 1.70 & 19.56 & 2.15 & 0.36 & 0.01 \\
\hline Mean $(n=14)$ & 54.36 & 0.39 & 2.58 & 18.43 & 1.66 & 19.51 & 2.59 & 0.47 & 0.02 \\
\hline $\mathrm{YTT}^{*}(\mathrm{n}=3)$ & 50.49 & 0.06 & 0.34 & 31.70 & 3.12 & 13.05 & 1.03 & 0.02 & - \\
\hline $\operatorname{MTT}^{*}(\mathrm{n}=3)$ & 49.40 & 0.08 & 0.33 & 37.52 & 2.24 & 09.49 & 1.03 & 0.03 & -- \\
\hline $\operatorname{OTT}^{*}(\mathrm{n}=2)$ & 50.49 & 0.09 & 0.47 & 34.02 & 1.86 & 11.60 & 1.09 & 0.03 & -- \\
\hline $\mathrm{HDT}^{*}(\mathrm{n}=2)$ & 52.03 & 0.12 & 1.10 & 23.62 & 0.64 & 20.64 & 1.26 & -- & -- \\
\hline $\begin{array}{l}\text { 1883-Krakatau } \\
(\mathrm{CIOB})^{\$}\end{array}$ & 52.59 & 0.18 & 0.72 & 17.57 & 1.24 & 25.34 & 1.20 & -- & -- \\
\hline $\begin{array}{l}\text { 1883-Krakatau } \\
\text { (proximal) }\end{array}$ & 53.44 & 0.27 & 0.67 & 18.48 & 1.43 & 24.17 & 1.30 & -- & -- \\
\hline
\end{tabular}

$\mathrm{n}=$ Number of samples. ${ }^{*}$ Chesner, 1998 -- no data

${ }^{\$}$ Mudholkar and Fujii, 1995

${ }^{\#}$ Camus et. al., 1987. 


\section{Table 4.}

\begin{tabular}{|c|c|c|c|c|c|c|c|c|c|c|c|c|c|c|c|c|c|c|c|c|c|c|c|c|}
\hline & \multicolumn{19}{|c|}{ Partially coated pumice } & \multicolumn{5}{|c|}{ Fully coated pumice } \\
\hline & $\begin{array}{l}\text { AAS- } \\
22 / 12\end{array}$ & $\begin{array}{c}\text { SS-16/ } \\
833 \mathrm{C}\end{array}$ & $\begin{array}{l}\text { AAS- } \\
26 / 14\end{array}$ & $\begin{array}{l}\text { AAS- } \\
22 / 10\end{array}$ & $\begin{array}{l}\text { AAS- } \\
26 / 38\end{array}$ & $\begin{array}{l}\mathrm{F}-2 / \\
75 \mathrm{E}\end{array}$ & $\begin{array}{l}F-2 / \\
61 F\end{array}$ & $\begin{array}{l}\text { AAS- } \\
22 / 11\end{array}$ & $\begin{array}{c}\mathrm{F}-1 / \\
2 \mathrm{E}\end{array}$ & $\begin{array}{c}\text { NR-4/ } \\
147 \mathrm{~A}\end{array}$ & $\begin{array}{c}\text { SK-23/ } \\
269 \mathrm{C}\end{array}$ & $\begin{array}{c}\text { AAS-2 } \\
10 \mathrm{~B}\end{array}$ & $\begin{array}{l}\text { AAS- } \\
22 / 14\end{array}$ & $\begin{array}{l}\text { AAS- } \\
22 / 9\end{array}$ & $\begin{array}{l}\mathrm{F}-2 / \\
78 \mathrm{D}\end{array}$ & $\begin{array}{l}\mathrm{F}-2 / \\
71 \mathrm{E}\end{array}$ & $\begin{array}{l}\text { F-2/ } \\
72 E\end{array}$ & $\begin{array}{c}\text { SK-23/ } \\
269 \mathrm{~F}\end{array}$ & $\begin{array}{l}\text { Mean } \\
(\mathrm{n}=18)\end{array}$ & $\begin{array}{c}\text { AAS- } \\
22 / \\
\text { D-09 }\end{array}$ & $\begin{array}{c}\text { AAS- } \\
22 / \\
\text { D-15 }\end{array}$ & \begin{tabular}{|c|} 
AAS- \\
$22 /$ \\
D-17
\end{tabular} & $\begin{array}{c}\text { AAS- } \\
22 / \\
\text { D-19 }\end{array}$ & $\begin{array}{l}\text { Mean } \\
(\mathrm{n}=4)\end{array}$ \\
\hline $\mathrm{La}$ & 30.6 & 30.6 & 25.0 & 20.6 & 29.8 & 27.9 & 22.3 & 22.5 & 26.5 & 34.8 & 22.6 & 23.5 & 16.0 & 21.7 & 19.7 & 18.2 & 22.7 & 15.7 & 23.9 & 31.6 & 26.3 & 36.0 & 29.0 & 30.7 \\
\hline $\mathrm{Ce}$ & 56.8 & 62.3 & 55.2 & 45.1 & 66.1 & 57.0 & 48.6 & 46.9 & 51.3 & 65.8 & 49.4 & 48.9 & 35.4 & 43.5 & 39.3 & 36.2 & 41.5 & 338 & 49.3 & 53.1 & 53.8 & 59.7 & 52.0 & 54.6 \\
\hline $\operatorname{Pr}$ & 5.12 & 6.14 & 5.89 & 4.97 & 7.44 & 6.10 & 5.34 & 4.10 & 5.31 & 6.80 & 5.40 & 5.07 & 4.00 & 4.24 & 3.87 & 3.82 & 3.89 & 4.50 & 5.11 & 4.65 & 5.77 & 5.28 & 5.35 & 5.26 \\
\hline $\mathrm{Nd}$ & 18.6 & 24.0 & 24.7 & 21.2 & 32.1 & 26.1 & 22.5 & 19.4 & 22.5 & 27.7 & 23.2 & 20.5 & 18.0 & 15.7 & 14.5 & 14.8 & 14.4 & 21.4 & 21.2 & 16.5 & 24.2 & 18.8 & 20.4 & 10.0 \\
\hline $\mathrm{Sm}$ & 2.96 & 3.74 & 4.67 & 4.22 & 6.29 & 5.53 & 4.38 & 3.59 & 4.55 & 4.63 & 4.53 & 3.72 & 3.84 & 2.55 & 2.43 & 2.98 & 2.35 & 5.02 & 4.00 & 2.80 & 5.22 & 3.20 & 3.66 & 3.72 \\
\hline $\mathrm{Eu}$ & 0.72 & 0.78 & 1.00 & 1.05 & 1.23 & 1.08 & 1.03 & 0.89 & 1.02 & 1.44 & 0.98 & 0.84 & 0.89 & 0.54 & 0.66 & 0.73 & 0.58 & 1.26 & 0.93 & 0.33 & 0.94 & 0.29 & 0.51 & 0.52 \\
\hline $\mathrm{Gd}$ & 3.28 & 3.61 & 4.44 & 3.96 & 5.67 & 4.95 & 3.81 & 3.41 & 4.83 & 4.89 & 3.93 & 3.42 & 3.53 & 2.65 & 2.33 & 2.55 & 2.28 & 4.46 & 3.78 & 2.46 & 4.31 & 2.66 & 2.97 & 3.10 \\
\hline $\mathrm{Tb}$ & 0.36 & 0.50 & 0.67 & 0.66 & 0.98 & 0.90 & 0.67 & 0.52 & 0.72 & 0.61 & 0.69 & 0.55 & 0.67 & 0.36 & 0.33 & 0.43 & 0.30 & 0.88 & 0.60 & 0.36 & 0.85 & 0.40 & 0.52 & 0.53 \\
\hline Dy & 1.73 & 2.60 & 3.81 & 4.06 & 5.66 & 5.36 & 3.98 & 2.93 & 4.38 & 3.16 & 4.16 & 3.13 & 4.16 & 1.89 & 1.83 & 2.39 & 1.50 & 5.85 & 3.48 & 2.07 & 5.67 & 2.26 & 3.33 & 3.33 \\
\hline Ho & 0.38 & 0.59 & 0.89 & 0.92 & 1.29 & 1.25 & 0.92 & 0.69 & 1.03 & 0.73 & 0.97 & 0.75 & 1.00 & 0.43 & 0.40 & 0.47 & 0.33 & 1.38 & 0.80 & 0.42 & 1.23 & 0.46 & 0.72 & 0.71 \\
\hline $\mathrm{Er}$ & 1.15 & 1.71 & 2.55 & 2.65 & 3.60 & 3.46 & 2.80 & 1.92 & 2.85 & 2.13 & 2.58 & 2.08 & 2.79 & 1.23 & 1.16 & 1.66 & 0.98 & 3.86 & 2.29 & 1.41 & 4.03 & 1.54 & 2.37 & 2.34 \\
\hline $\mathrm{Tm}$ & 0.17 & 0.29 & 0.41 & 0.43 & 0.60 & 0.59 & 0.47 & 0.33 & 0.48 & 0.35 & 0.43 & 0.35 & 0.47 & 0.21 & 0.19 & 0.29 & 0.16 & 0.65 & 0.38 & 0.23 & 0.62 & 0.24 & 0.40 & 0.37 \\
\hline $\mathrm{Yb}$ & 1.18 & 1.86 & 2.88 & 2.70 & 3.63 & 3.53 & 2.95 & 2.16 & 2.95 & 2.35 & 2.74 & 2.23 & 3.05 & 1.33 & 1.28 & 2.00 & 1.04 & 4.02 & 2.44 & 1.46 & 3.84 & 1.59 & 2.51 & 2.35 \\
\hline$\overline{\mathrm{Lu}}$ & 0.19 & 0.30 & 0.46 & 0.43 & 0.58 & 0.56 & 0.48 & 0.35 & 0.48 & 0.40 & 0.44 & 0.36 & 0.48 & 0.21 & 0.21 & 0.32 & 0.17 & 0.63 & 0.39 & 0.24 & 0.64 & 0.27 & 0.43 & 0.40 \\
\hline $\mathrm{Sc}$ & 6.09 & 4.97 & 6.75 & 10.16 & 9.09 & 10.7 & 5.81 & 5.42 & 7.52 & 3.69 & 8.36 & 4.27 & 8.97 & 4.31 & 4.63 & 5.81 & 3.42 & 14.23 & 6.90 & 5.01 & 9.99 & 2.58 & 4.73 & 5.58 \\
\hline $\mathrm{Co}$ & 1.45 & 1.31 & 1.78 & 1.92 & 1.13 & 2.56 & 1.28 & 1.48 & 1.03 & 1.68 & 1.31 & 1.19 & 1.57 & 0.98 & 2.52 & 1.45 & 1.02 & 3.20 & 1.60 & 1.40 & 1.83 & 0.74 & 1.54 & 1.38 \\
\hline $\mathrm{Ni}$ & 2.86 & 2.45 & 1.71 & 4.28 & 1.60 & 1.40 & 1.18 & 1.60 & 2.09 & 2.21 & 2.31 & 1.29 & 2.88 & 1.25 & 1.46 & 2.41 & 2.20 & 2.65 & 2.10 & 16.1 & 13.5 & 3.79 & 18.0 & 12.8 \\
\hline $\mathrm{Rb}$ & 131 & 147 & 70.0 & 79.7 & 115 & 109 & 66.9 & 89.0 & 110 & 83.8 & 90.9 & 92.1 & 47.0 & 123 & 90.5 & 58.8 & 151 & 45.6 & 94.5 & 137 & 99 & 151 & 128 & 129 \\
\hline $\mathrm{Y}$ & 10.9 & 19.2 & 23.6 & 27.3 & 33.2 & 32.7 & 25.5 & 19.1 & 25.9 & 20.8 & 24.3 & 20.6 & 27.4 & 12.5 & 11.8 & 16.1 & 10.9 & 34.5 & 22.0 & 13.6 & 36.8 & 14.5 & 22.15 & 21.75 \\
\hline $\mathrm{Zr}$ & 266 & 165 & 200 & 246 & 181 & 225 & 197 & 182 & 247 & 198 & 302 & 156 & 263 & 151 & 106 & 277 & 295 & 260 & 218 & 324 & 270 & 145 & 227 & 241 \\
\hline $\mathrm{Nb}$ & 22.2 & 10.0 & 9.34 & 12.1 & 10.9 & 12.7 & 9.02 & 9.98 & 16.1 & 12.8 & 20.8 & 7.61 & 12.8 & 10.5 & 7.20 & 17.6 & 22.9 & 12.6 & 13.2 & 12.9 & 8.54 & 6.31 & 7.95 & 8.93 \\
\hline Cs & 12.4 & 8.73 & 2.80 & 4.09 & 6.45 & 7.12 & 2.30 & 4.57 & 7.65 & 7.28 & 5.20 & 4.35 & 2.41 & 8.61 & 5.37 & 2.97 & 8.73 & 3.00 & 5.78 & 12.5 & 5.59 & 14.1 & 8.11 & 10.1 \\
\hline Hf & 7.65 & 4.51 & 5.61 & 6.13 & 5.56 & 6.16 & 5.54 & 5.24 & 7.10 & 5.24 & 8.55 & 4.48 & 7.10 & 4.38 & 3.21 & 6.96 & 7.25 & 7.83 & 6.03 & 8.24 & 7.80 & 4.52 & 7.11 & 6.92 \\
\hline
\end{tabular}




\begin{tabular}{|l|l|l|l|l|l|l|l|l|l|l|l|l|l|l|l|l|l|l|l|l|l|l|l|l|l|}
\hline Ta & 1.19 & 0.56 & 0.57 & 0.54 & 0.69 & 0.60 & 0.51 & 0.66 & 1.01 & 0.56 & 1.00 & 0.46 & 0.47 & 0.71 & 0.54 & 0.83 & 0.44 & 0.53 & 0.66 & 0.54 & 0.42 & 0.38 & 0.51 & 0.46 \\
\hline Th & 27.8 & 16.0 & 13.9 & 8.00 & 19.4 & 16.5 & 9.38 & 14.9 & 25.8 & 19.1 & 21.2 & 11.9 & 9.02 & 20.6 & 13.3 & 11.5 & 11.2 & 7.95 & 15.4 & 18.6 & 17.8 & 20.7 & 23.5 & 20.1 \\
\hline U & 6.65 & 4.34 & 2.74 & 1.76 & 4.06 & 4.06 & 2.19 & 2.65 & 4.77 & 3.87 & 3.25 & 2.47 & 1.46 & 4.54 & 2.65 & 1.87 & 3.39 & 1.30 & 3.22 & 5.07 & 3.01 & 6.18 & 4.76 & 4.76 \\
\hline
\end{tabular}


Table 5.

\begin{tabular}{|l|c|c|c|c|}
\hline $\begin{array}{c}\text { Oxides } \\
(\%)\end{array}$ & $\begin{array}{c}\text { Partialy coated } \\
\text { pumice*CIOB } \\
(\mathrm{n}=67)\end{array}$ & $\begin{array}{c}\text { YTT- } \\
\text { CIOB } \\
@\end{array}$ & $\begin{array}{c}\text { MTT - } \\
\text { Layer-C, } \\
\text { ODP-758 } \$\end{array}$ & $\begin{array}{c}\text { OTT - } \\
\text { CIOB } \\
\#\end{array}$ \\
\hline $\mathrm{SiO}_{2}$ & 77.23 & 76.81 & 77.57 & 77.33 \\
\hline $\mathrm{TiO}_{2}$ & 0.23 & 0.07 & 0.06 & 0.05 \\
\hline $\mathrm{Al}_{2} \mathrm{O}_{3}$ & 13.27 & 12.77 & 12.24 & 12.70 \\
\hline $\mathrm{Fe}_{2} \mathrm{O}_{3}$ & 1.32 & 0.92 & 1.02 & 0.86 \\
\hline $\mathrm{MnO}$ & 0.10 & 0.06 & 0.04 & 0.07 \\
\hline $\mathrm{MgO}$ & 0.30 & 0.05 & 0.04 & 0.07 \\
\hline $\mathrm{CaO}$ & 1.41 & 0.79 & 0.63 & 0.77 \\
\hline $\mathrm{Na}_{2} \mathrm{O}$ & 4.95 & 3.41 & 3.55 & 2.84 \\
\hline $\mathrm{K}_{2} \mathrm{O}$ & 2.00 & 5.08 & 4.73 & 5.18 \\
\hline $\mathrm{P}_{2} \mathrm{O}_{5}$ & 0.18 & 0.16 & 0.12 & 0.20 \\
\hline
\end{tabular}

*-Present study, @-Pattan et al., 1999 ; \$-Westgate et al., 1998, \#-Pattan et al., 2010. 
Table 6.

\begin{tabular}{|l|c|c|c|c|c|c|c|c|}
\hline Oxides & $\begin{array}{c}\text { Partially } \\
\text { coated } \\
\text { pumice* } \\
(\mathrm{n}=11)\end{array}$ & $\begin{array}{c}\text { Fully } \\
\text { coated } \\
\text { pumice* } \\
(\mathrm{n}=4)\end{array}$ & $\begin{array}{c}\text { MTT- } \\
\text { Fiamme } \\
(\mathrm{n}=2)\end{array}$ & $\begin{array}{c}\text { MTT- } \\
\text { welded } \\
\text { tuff, } \$ \\
(\mathrm{n}=3)\end{array}$ & $\begin{array}{c}\text { OTT- } \\
\text { Fiamme } \\
\# \\
(\mathrm{n}=15)\end{array}$ & $\begin{array}{c}\text { OTT- } \\
\text { welded } \\
\text { tuff, } \$ \\
(\mathrm{n}=3)\end{array}$ & $\begin{array}{c}\text { HDT- } \\
\text { Fiamme } \\
\# \\
(\mathrm{n}=1)\end{array}$ & $\begin{array}{c}\text { HDT- } \\
\text { welded tuff } \\
\# \\
(\mathrm{n}=1)\end{array}$ \\
\hline $\mathrm{SiO}_{2}$ & 77.06 & 75.15 & 73.97 & 76.16 & 68.49 & 71.22 & 65.53 & 63.85 \\
\hline $\mathrm{TiO}_{2}$ & 0.36 & 0.32 & 0.23 & 0.18 & 0.52 & 0.37 & 0.73 & 0.67 \\
\hline $\mathrm{Al}_{2} \mathrm{O}_{3}$ & 13.02 & 13.79 & 13.76 & 13.59 & 15.35 & 14.33 & 16.42 & 16.29 \\
\hline $\mathrm{Fe}_{2} \mathrm{O}_{3}$ & 1.91 & 2.00 & 2.99 & 1.34 & 3.64 & 3.12 & 5.03 & 6.06 \\
\hline $\mathrm{MnO}$ & 0.21 & 0.08 & 0.05 & 0.03 & 0.06 & 0.07 & 0.08 & 0.11 \\
\hline $\mathrm{MgO}^{2}$ & 0.42 & 0.45 & 0.30 & 0.28 & 1.04 & 0.73 & 1.22 & 1.61 \\
\hline $\mathrm{CaO}^{2}$ & 1.41 & 1.18 & 1.26 & 1.18 & 3.27 & 2.65 & 4.73 & 5.44 \\
\hline $\mathrm{Na}_{2} \mathrm{O}$ & 3.08 & 3.54 & 3.06 & 2.87 & 3.65 & 3.44 & 2.68 & 2.79 \\
\hline $\mathrm{K}_{2} \mathrm{O}$ & 2.49 & 3.49 & 4.31 & 4.35 & 3.83 & 3.97 & 3.44 & 3.00 \\
\hline $\mathrm{P}_{2} \mathrm{O}_{5}$ & 0.04 & 0.05 & 0.02 & 0.02 & 0.14 & 0.11 & 0.14 & 0.17 \\
\hline
\end{tabular}

* Present study. \# -Chesner, 1998; \$- Chesner and Luhr, 2010. n =number of samples analysed. 


\section{Captions for figures}

Figure1. Location map showing occurrence of pumice field in Central Indian Ocean Basin. (Figure source: Weisberg and Parish, 1974, p-146).

Figure 2. (a) Microphotograph showing mineral clots of ortho-pyroxene (OPX) along with dark black coloured spinel (Sp) in a glassy matrix. (b) Microphotograph showing mineral clots with amphibole and plagioclase laths. (c) Microphotograph exhibiting flow texture. (d). Scanning Electron Microphotograph exhibiting Mn-oxide precipitation like a botryoid.

Figure.3. Scatter plots of $\mathrm{SiO}_{2}(\mathrm{wt} \%)$ with $\mathrm{Al}_{2} \mathrm{O}_{3}(\mathrm{wt} \%), \mathrm{K}_{2} \mathrm{O}(\mathrm{wt} \%)$, and $\mathrm{Fe}_{2} \mathrm{O}_{3}(\mathrm{wt} \%)$, for both partially and fully coated pumice from CIOB. Note a single regression is valid for the entire data.

Figure 4. Composition of orthopyroxene from partially coated pumice of CIOB (1) present study and compared with orthopyroxene from, (2) 1883-Krakatau, (3)-YTT, (4)-MTT , (5)OTT and (6) HDT in a Ca-Fe-Mg diagram

Figure 5. Glass chemistry from coated and leached pumice sample AAS-26/D14 determined by EPMA. Note the negative correlation $(\mathrm{r}=-0.61)$ between $\mathrm{K}_{2} \mathrm{O}$ and $\mathrm{Na}_{2} \mathrm{O}$.

Figure 6. Chondrite-normalized REE pattern

(a) Partially coated pumice

(b) Fully coated pumice

(c) and comparison of partially and fully coated pumice from CIOB with uncoated pumice from CIOB, YTT, MTT and OTT. Shaded area is field of composition of rhyolitic rocks from Sumatra (Ikeda et al., 1980, Masuda, 1980).

Figure 7 (a) Tectonomagmatic discrimination diagram based on Y vs. Nb for partially coated pumice (open triangle), fully coated pumice (filled triangle) and uncoated pumice (cross) from CIOB (Winchester and Floyd, 1977).

(b) Ternary diagram of Ti-Zr-Y for volcanic samples.1- partially coated pumice from CIOB (open triangle), 2- fully coated pumice from CIOB (filled triangle),

3-6 are altered ash layers of Miocene age from CIOB (Martin-Barajas and LallierVerges, 1993). Hatched area is for volcanic arc related rhyolite tephra (Yamamoto et al., 1986). 
Figure1

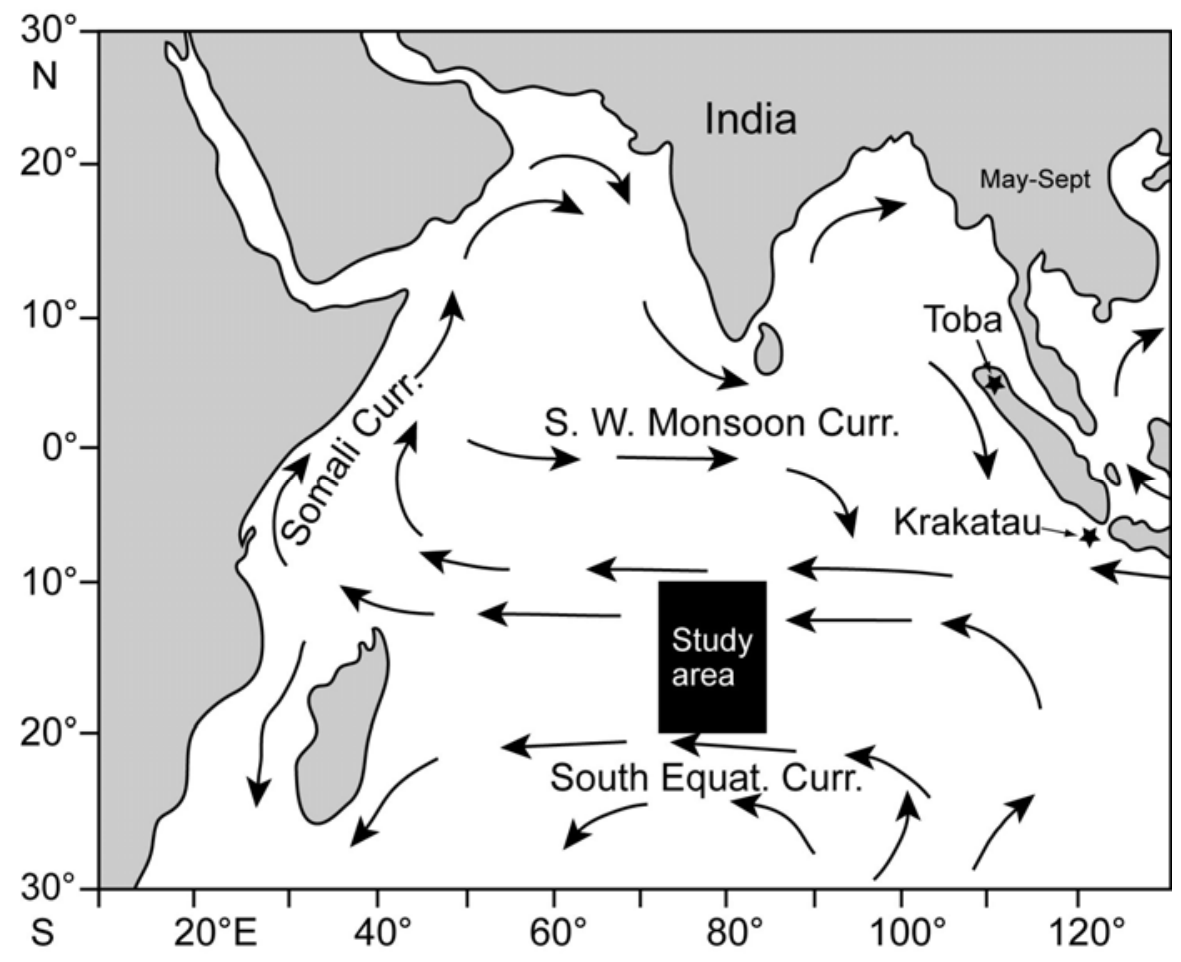

Figure 2
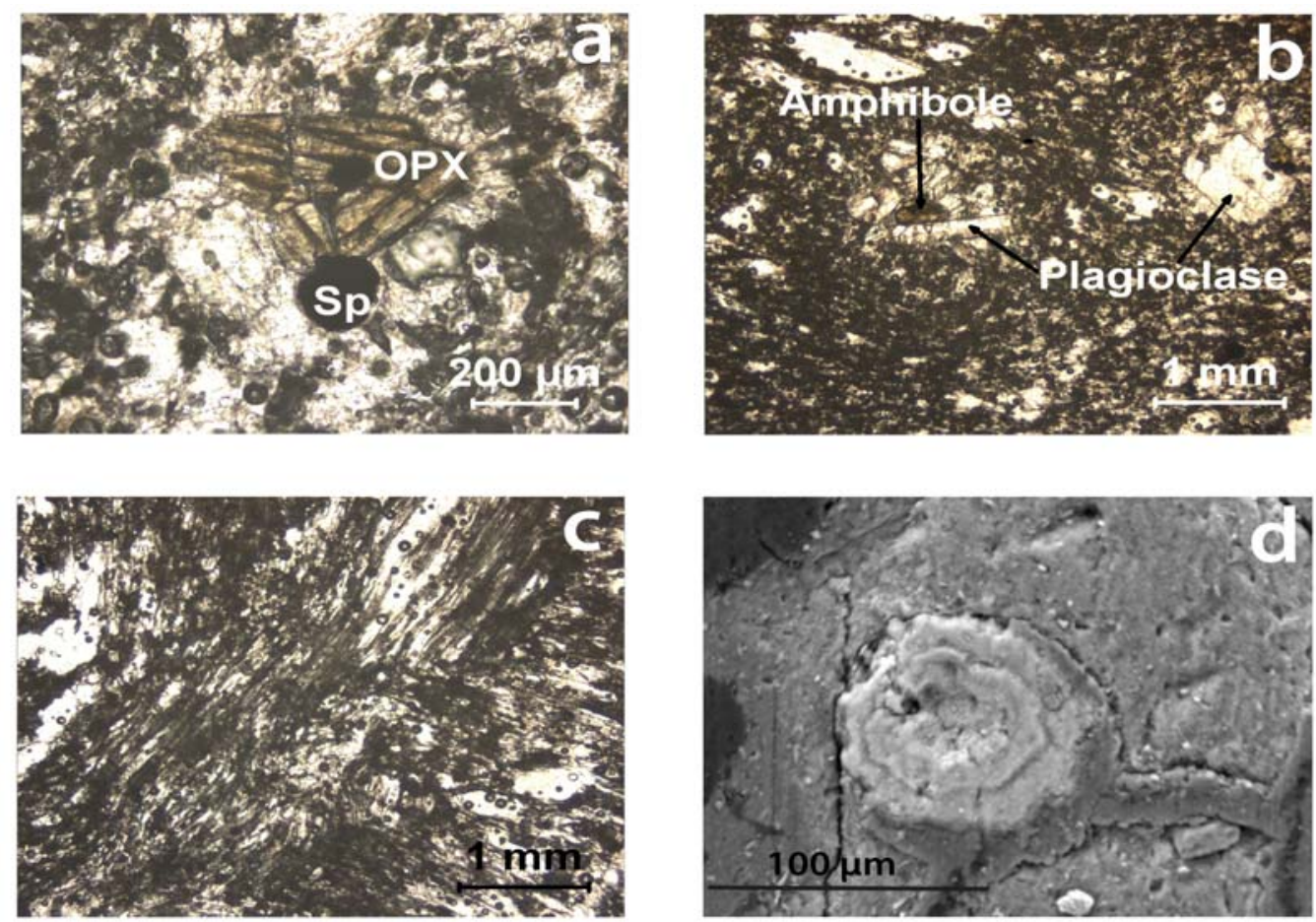
Figure 3
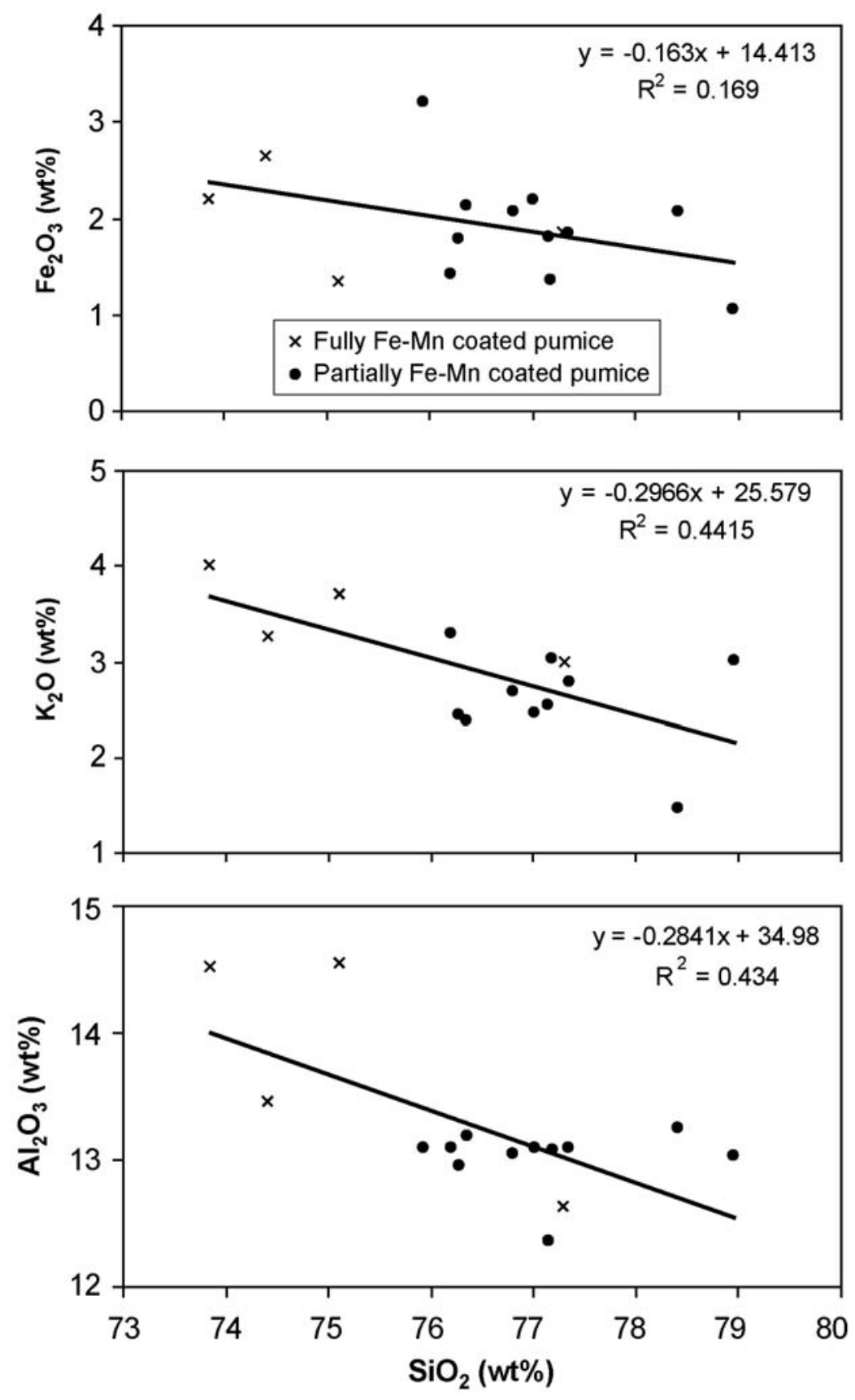
Figure 4

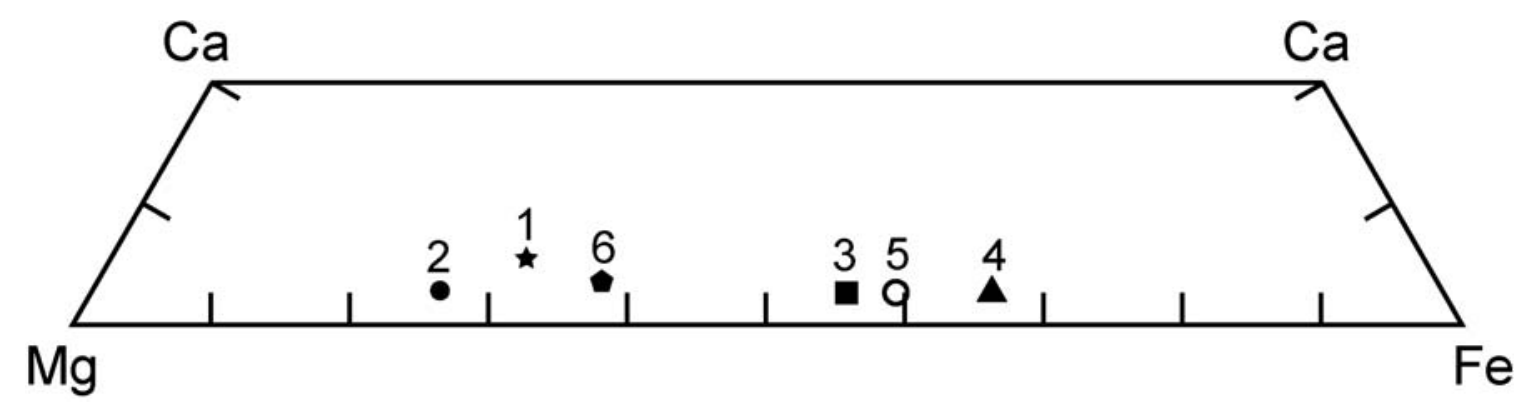

Figure 5

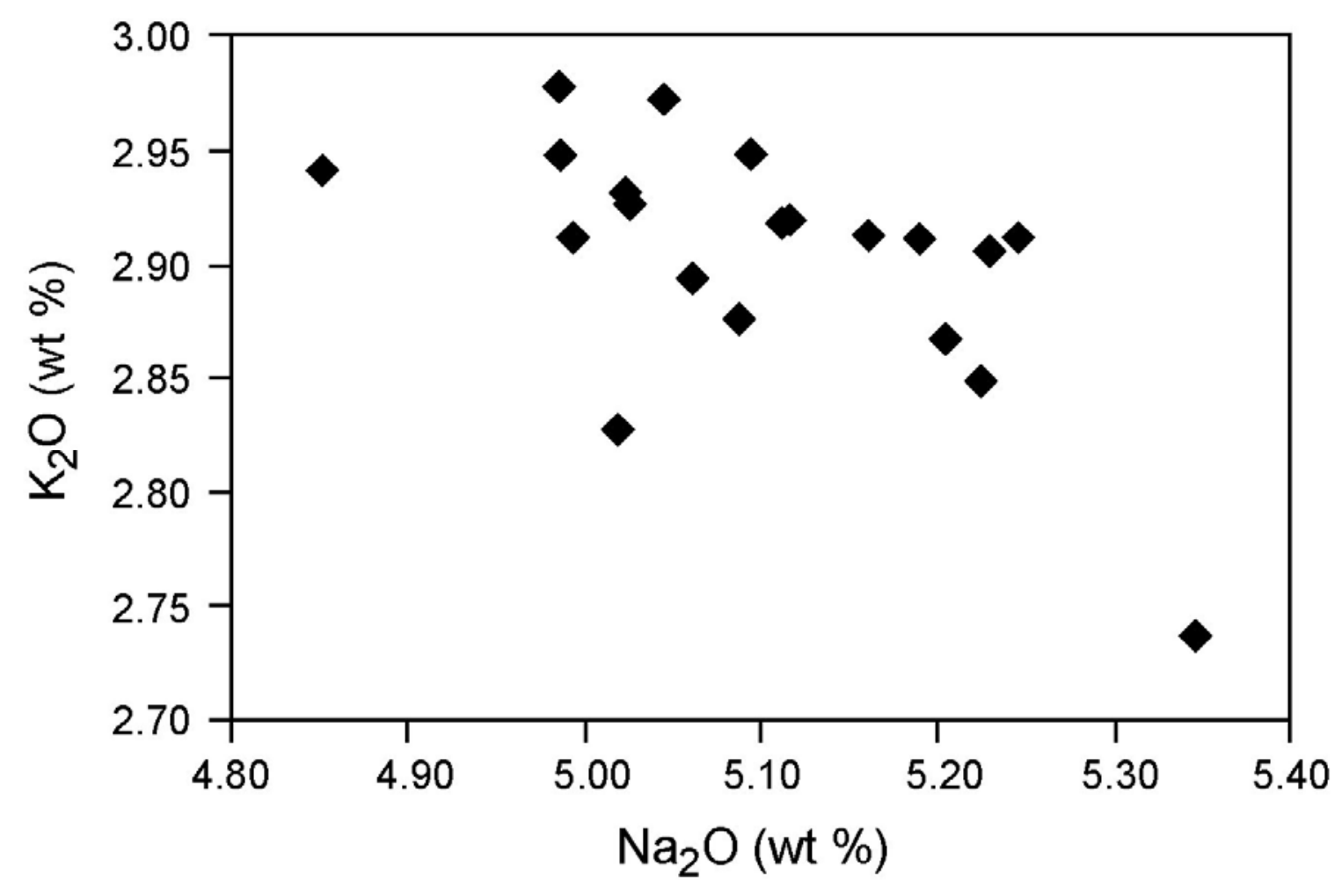


Figure 6

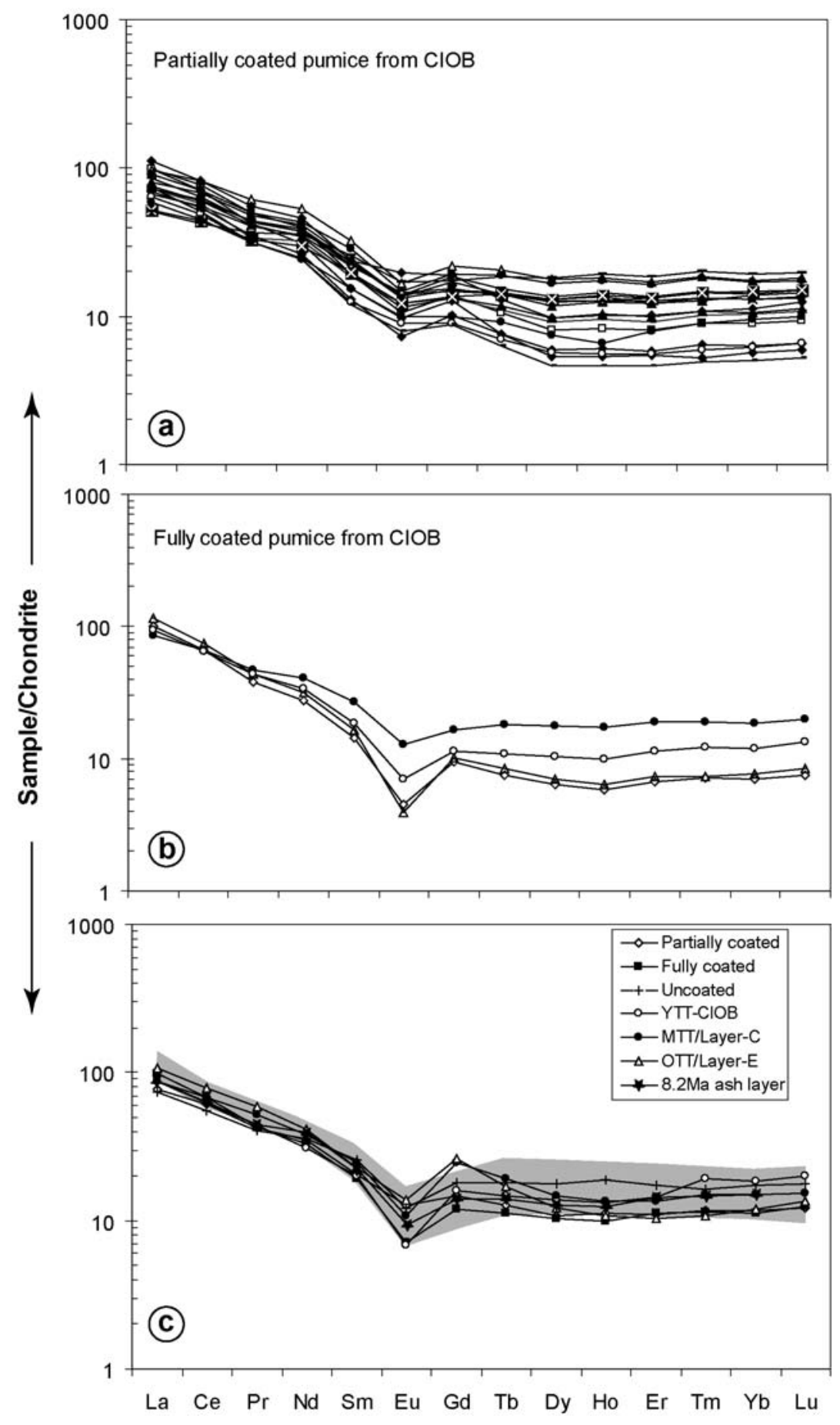


Figure 7
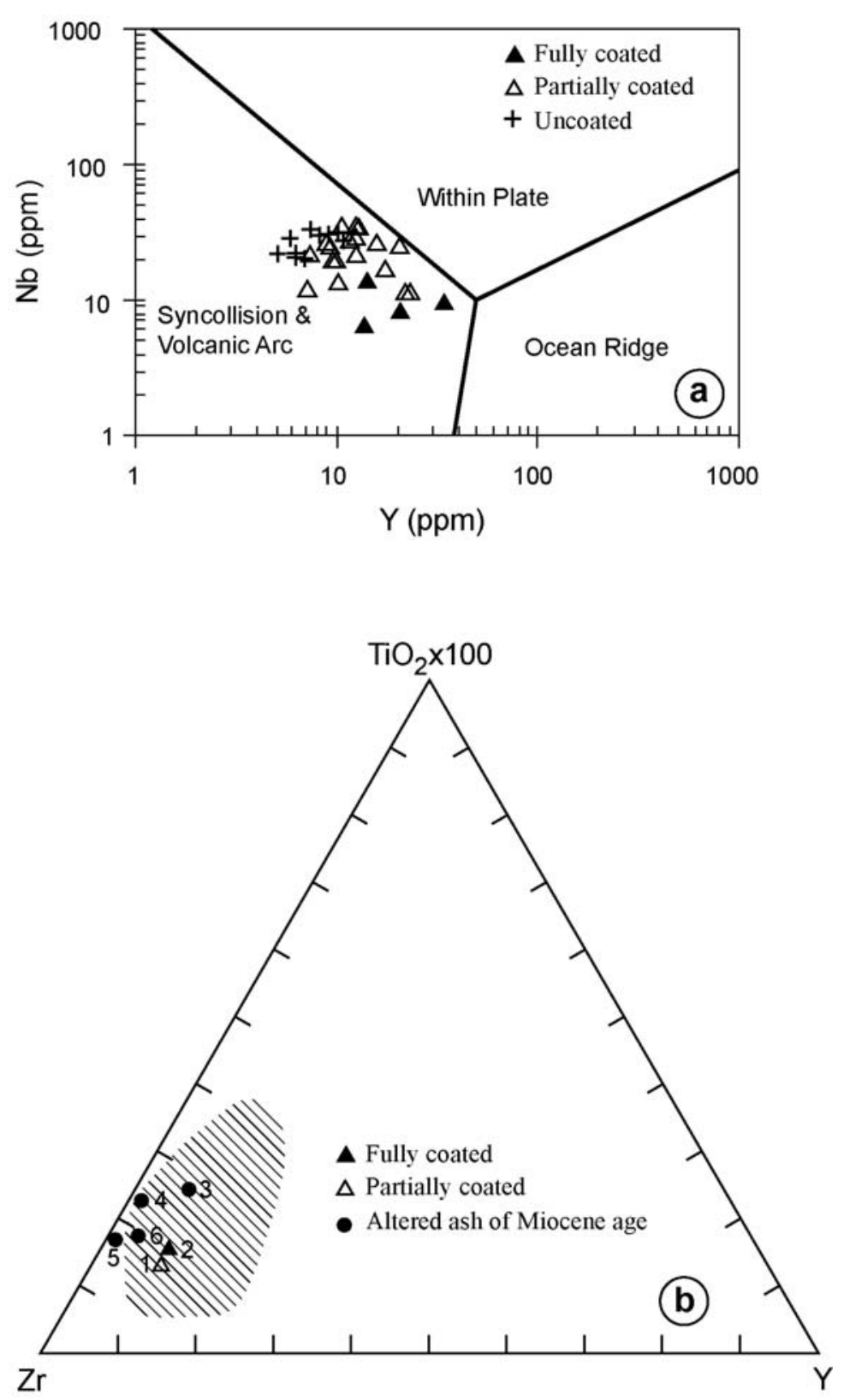